\title{
БУРХАН БУУДАЙН НУРУУНЫ ФИЗИК ГАЗАРЗУЙН ТОДОРХОЙЛОЛТ
}

\author{
Э.Авирмэд ${ }^{1}$, Б.Баянжсаргал ${ }^{1}$ \\ ШУА-ийн Газарзуйн хүрээлэн \\ Цахим иуудан: avirmed_cave@yahoo.com
}

\begin{abstract}
Mountain Burkhan Buudai is one of the mountain systems of Mongol Altai, which is located at the end part of Mongol Altai mountain. Mountain Burkhan Buudai is similar with surface typology, deposits, relief form, erosion and accumlation proccess, mountain side, dissection, age and landscape of main mountains of Mongol Altai.

The mountain Burkhan Buudai segregated to the east by Biger's depression, to the north from mountain of Bumban Ulaan by valley Chachran river to the west from main mountains Altai by valley of the Sagsaa river to the south by kotal and valley of Dut from mountain Sair and Taskhir Khaalga. The highest peak this mountain Burkhan Buudai uul $3093.3 \mathrm{~m}$ high above the sea level. The relief of mountain and peak of a mountain is mostly cupola or plane shaped because of in longest time weathered by wind and water.
\end{abstract}

\section{ОРШИЛ}

Монгол Алтайн нурууг бүрэлдүүлж байгаа томоохон уулсын нэг Бурхан Буудай уулын физик газарзүйн тодорхойлолт байдаггүй юм. Бурхан буудай уул нь Монгол Алтайн уулт тогтолцооны төгсгөл хэсэгт Хар азаргын нуруу, Гичгэнийн нурууны хооронд Монгол Алтайн уулт тогтолцооны зүүн захаар, Бигэр нуурын хотгорыг зүүн талаар нь хүрээлэн тогтсон уулт тогтолцоо юм. Бурхан буудай уул нь ихэнхдээ протерзой, палеозойн эриний венд-түрүү кембрийн болон девоны галвын хурдаснаас бүрэлдэн тогтсон эгц цавчим хажуутай, бөмбөгөр оройтой, хэрчигдсэн, хурдас чулуулгийнхаа онцлогтой холбоотой давчуу гүн голын хөндийгөөр огтлогдсон байдаг юм. Бурхан буудай уул нь хурдас чулуулаг, гадаргын хэв шинж, хэлбэр, элэгдэл хуримтлалын хэлбэрүүд, уулсын хажуу, хэрчигдэл, нас, ландшафтын хувьд Монгол Алтайн уулстай адилхан юм. Бурхан буудай уул $126,838.3$ га талбайг эзлэн орших ба нийт хилийнх нь урт 176.0 км урт юм.

ТҮлхүҮр Үг. Бурхан буудай, Уулт тогтолиоо, гол нуруу, гадаргын хэв шинж, хэлбэр, хажуу, бэл, хөндий, уулс хоорондын хөндий, мөстөл

\section{СУДАЛГААНЫ МАТЕРИАЛ, АРГА ЗУЙ}

2007онд Монгол-Японы хамтарсан газрын хагарлын хээрийн судалгаа, 2011 онд Хар азаргын нурууг улсын тусгай хамгаалалтанд авах судалгааны ажлын далимд Бурхан буудай ууланд геоморфологийн судалгаа, бичиглэл, хэмжилт хийж энэ нурууны товч тодорхойлолтыг хийсэн юм. Гадаргын хэв шинж, гадаргын үүсэл, хөгжил, геоморфологийн анализ, гадаргын хэв шинж, гадаргын хэлбэр, гадаргын хэрчигдлийн шигүу, гадаргын налуу, хурдасны зузаан, фаци, хурдас чулуулгийн өнгө бүтэц, палеогеоморфологийн анализ, 
эдэгдлийн хэлбэрүүд, ус зүйн сүлжээ, дэнж, голын хөндий, дэнжийн судалгааг хийж, 1:100 000-ны масштабтай байрзүйн зураг, SRTM-ийн өндрийн мэдээ болон Landsat хиймэл дагуулын сансрын зургийг ашиглан

\section{СУДЛАГДСАН БАЙДАЛ}

Монгол Алтайн гол нурууны тухай судлаачид өөр өөрсдийн хийсэн судалгааны дүгнэлтийг үлдээсэн байдаг.

1952 онд нэрт газарзүйч, судлаач Э.М.Мурзаев Монгольская Народная Республика /Физико-географические гадаргын налуу, өндөршлийн зургийг зохиож, сансрын зураг ашиглан гүний хагарлын шугам, гадаргын хэлбэрүүдийг сансрын зураг дээр тодруулалт хийх, харьцуулах аргаар судалгааг хийсэн болно.

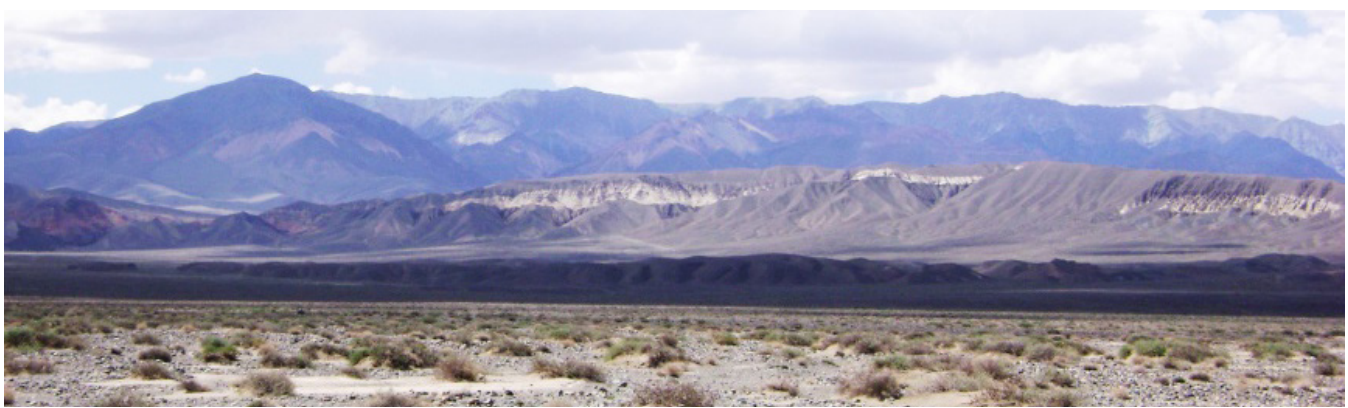

Академич Ш.Цэгмид Монгол орны физик газарзүй номондоо... Монгол Алтайн нурууд зүүн өмнө чиглэлийг яг дагаж тогтсоноор барахгүй салбарууд нь ч гэсэн мөн ойролцоо чиглэлтэй юм. Уулсын орой хяр голдуу хавтгай, хажуунууд нь нилээн эгц буюу өөрөөр хэлбэл ерөнхийдөө эртний тэгшрэлийн гадарга геологийн хожуу үед өргөгдсөн байдалтай ажээ. Орой, хярын хавтгай гадарга заримдаа их хэмжээний талбай эзэлж түүн дээр өндөр сүрлэг шовх оргил тод сүндэрлэж харагдана. Тийм описание/ номондоо “...Жинхэнэ Монгол Алтайн нурууны хамгийн сүүлчийн хэлхээ уулс бол Гичгэний нуруу энэ нуруунаас зүүн тийш нэгдсэн усан хагалбартай нурууд үргэлжлэх нь хүндрэлтэй болдог... гэжээ [1].

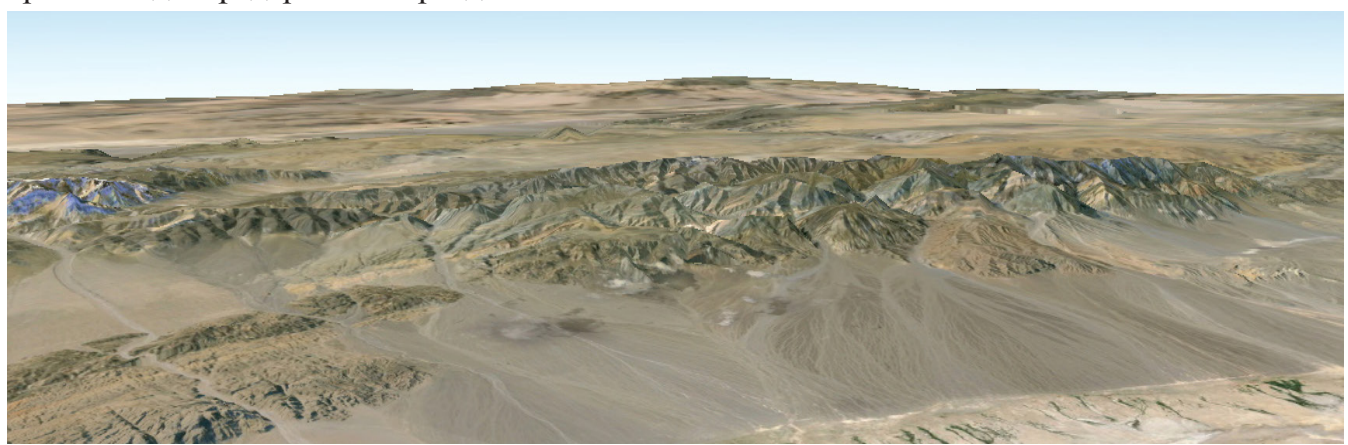

өргөн гадарга яг тэгш талын байдалтай биш, ялихгүй гүдгэр гүвээнүүдтэй байдгийг үзэхэд дээш өргөгдсөн эртний тэгшрэлийн гадарга мөн гэдэг нь илэрхий. Энэ гадарга геологийн тооллоор хожуу үед өргөгдсөн болохоор усанд сайн идэгдэж амжаагүй, харин хажуунууд нь хүчтэй идэгдэж эгц болжээ. Эндэхийн нурууд дөрөвдөгч галавын үед ихээхэн мөсдөж байсны ор мөр ялангуяа хамгийн өндөр баруун хагаст тун элбэг байна гэжээ [2]. 
Монгол Алтайн уулт тогтолцоонд Бурханбуудайн нуруунь уулзүйн байршлын хувьд гол нуруу болж байгаа учраас, мөн энэ нуруунаас салбарласан уул нуруу байдаггүй тул энэ нурууг Монгол Алтайн гол нуруу гэж үзэж байгаа юм. Тэгээд ч

\section{СУДАЛГААНЫ АЖЛЫН УР ДУН}

Уулзүйн байрлал: Бурхан буудай уул нь Монгол Алтайн уулт тогтолцооны төгсгөл хэсгийн зүүн захаар, Хар азаргын нуруу, Гичгэнийн нурууны хооронд баруун хойноосоо зүүн урагш 71 км үргэлжлэн Бигэр нуурын хотгорын зүүн урд талаар нь хүрээлэн тогтсон уулт тогтолцооны нэг. Алтайн уулт тогтолцоонд багтддаг Бурхан буудайн нуруу нь уулзүйн тогтолцоогоороо Монгол Алтайн гол нуруунд хамаарагдана.

Бурхан буудайн нурууг В.М.Синицын (1959) Монгол Алтайн нурууг Алаг нуурын хотгор хүртэл үргэлжилнэ гэж Говийн Алтайд оруулсан ба Э.М. Мурзаев (1952) Монгол Алтайн нурууны төгсгөлийг Гичгэний нуруугаар авч Монгол Алтайн нуруунд оуулжээ. Ш.Цэгмид (1969)
Бурхан буудайн нуруу нь хурдас чулуулаг, гадаргын хэв шинж, хэлбэр, элементүүд, элэгдэл хуримтлалын хэлбэрүүд, уулсын хажуу, хэрчигдэл, нас, ландшафтын хувьд Монгол Алтайн нурууны өндөр уулстай адилхан юм.

Гичгэний нурууг Монгол Алтайн төгсгөл гэж Монгол Алтайн нуруунд багтаасан бол С.Жигж (1975) геоморфологийн мужлалтандаа Монгол Алтайн гол нуруунд багтаасан байдаг юм.

Эндэхийн уулс тектоник бүтцээрээ дунд төрмөлийн настай Алтайн тогтолцоонд хамрана. Алтайн гол нуруутай адил баруун хойноос зүүн урагш сунаж орших ба ихээхэн элэгдэж хэрчигдсэний дээр хормойн хурдас нэн түгээмэл бөгөөд гуу жалга, хуурай сайраар хэрчигдэж бартаа ихтэй болжээ [3].

Алтайн уулсын хойт хажуугийн дагуу зэргэлдээ орших гүний тектоник ангал олон тул ерөнхийдөө Алтайн уулт тогтолцооны ар хажууд мөргөцөг үүсэн тогтжээ.

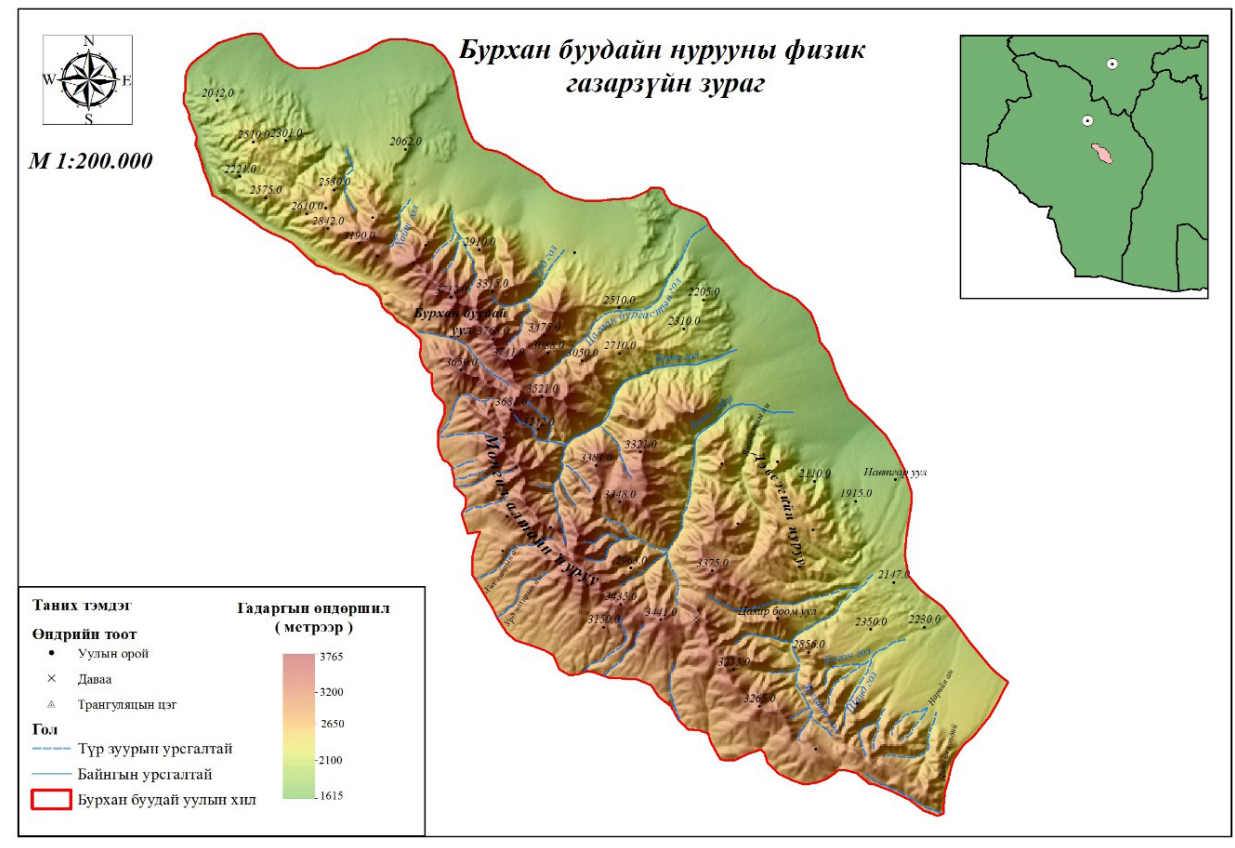


Бурхан буудай уул нь Монгол Алтайн гол нурууны нэгэн адил баруун хойноосоо зүҮн урагш 71.0 км сунан тогтсон уулс юм. Хойд талаараа Халиуны хоолой, Намалзахын голоор, зүүн талаараа Бигэр нуурын хотгороор Хөх сэрхийн нуруунаас, өмнө талаараа Сайрын эх нуруунаас Дөтийн давааны голын хөндий болон Тахилгын гол, Дөтийн даваагаар Цахир хаалгын нуруунаас тусгаарлагдана. Баруун хойд талаараа Уст Чацрангийн голоор Бумбан-Улааны нуруунаас, Баруун талаараа Сагсаагийн голын эхний хөндийгөөр Монгол Алтайн гол нуруунаас тусгаарлагдана.

Тус нурууны хойд захын цэг нь солбицол 96²8'28.73”, 4549'37.07'"-д орших 2042.0 тоот өндөрлөг, өмнөт захын цэг нь солбицол 9709'21.93”, 4525'28.78”-д орших Дөтийн хөндийн Хөшөө булаг, зүүн захын цэг нь солбицол 9703'51.98”, 453' 18.53 ”-д орших Дэвсэгийн нурууны 2348.0 тоот өндөрлөг, баруун захын цэг нь солбицол 960 45’32.64”, 4532’27.50”-д орших Хөх Сайрын ам юм.

Бурхан Буудайн нуруу нь Бигэр нуурын

\section{ГЕОЛОГИЙН ТОГТОЦ}

Бурхан Буудай уулын төв хэсэг нь мезозойн эрины дивоны дунд галвын хурдаснаас тогтсон бөгөөд уулс бүхэлдээ палеозойн эрины кембрийн эхэн болон дунд үеийн хурдас $\left(\Theta_{1-2}\right)$, венд- кембрийн түрүҮ үеийн хурдаснаас $\left(\mathrm{V}-\Theta_{1-2}\right)$ тогтсон байна. Уулын зүүн бэлээр Бигэрийн хотгор луу хошууран орсон багахан хэсэгт юра $\left(\mathrm{J}_{3}\right)$, цэрдийн галавын $\left(\mathrm{K}_{1}\right)$ хурдас эмжээрлэн тогтсон байна [4].

Дөрөвдөгч галвын эхээр уул тогтоох альпийн хөдөлгөөн үргэлжилж хотгор гүдгэр өөрчлөгдөн байгуулагдах үйл явц болсоор байв. Энэ тектоник хөдөлгөөн нийтдээ эрч ихтэй боловч тус орны нутаг бүрд жигд хүчтэй явагдсангүй. Түүний хүч баруун болон хойд зүгийн нутагт нэн их байсан тул хуучин уулт нутгийг өндөрт өргөснөөр Алтай, Хангай, Хэнтийн нуруу хотгорын баруун талын усан хагалбар болно. 3100-3700 м өндөр сүндэрдэсэн оройтой эгц хажуу бүхий дундаж өндөр уулс, тэдгээрээс эх аван урсах голуудын хөндий хосолсон томоохон нуруу юм. Далайн түвшнээс дээш дунджаар 20003100 м өндөр өргөгдсөн баруун хойноос зүүн урагш 71.0 км сунаж тогтсон хамгийн өргөн газраа 23.6 км, нарийн газраа 6.4 км өргөнтэй юм. Тус нурууны хамгийн өндөр ноён оргил нь Бурхан буудай уул 3765.0 м өндөрт сүндэрлэнэ. Бурхан буудайн гол нурууны оргилууд бүгд 3400 метрээс дээш өндөрэй юм. Тус нурууны уулсын $19.8 \%$ буюу 25225.9 га нутаг дэвсгэр 3000 метрээс дээш өндөртэй юм. Баруун захын Тогол Хайрхан уул (3081.6м), Хөндлөн Хайрхан (3009.0 м) өндөр юм. Энэ нуруу морфогенетик хэв шинжийн хувьд тектоник-элэгдлийн хэв шинжит хотгор гүдгэр болох дундаж өндөр уул (2000-3000 м)-т тогтолцоонд хамаарна. Бурхан Буудайн нурууны баруун хажуу нь эгц цавчим бөгөөд шинэсэн ойн хил $2500 \mathrm{M}$ өндрөөс эхлэх боловч ой тархац бага байна.

одооныхоо байдлын олж авчээ. Нурууны хажуу баруун хэсэгтээ хэм тэгш биш, урд талынх нь эгц байсан бол энэ хэсэгт хойт талын хажуу Шаргын говь, Бигэрийн хонхор зэрэг нилээд доор түвшинд буй хотгорууд руу харсан тал эгц болж ирнэ. [1]

Бурхан буудайн нурууны баруун биеэр дайран гарсан уулын дагуу чиглэлтэй эртний томоохон тектоник хагарлуудын ул мөр хадаглагдаж үлджээ. Эдгээр хагарлуудыг даган тогтсон уулс хоорондын хөндийгөөр энэ нуруу Монгол Алтайн гол нуруунаас зааглагдаж байдаг юм. Бурхан буудайн нуруунд сүүлийн үеийн хагарал гадаргад ажиглагдахгүй байна.

Бурхан буудайн нуруу нь маш гүн хэрчигдсэн, уулсын хажуу маш их налуу, заримдаa бараг эгц хажууг үүсгэсэн байна. Ихэнх төлөв хавцал үүсгэсэн 
бий. Ерөнхийдөө нарийн хавцлын хэсэг нь үндсэн чулуулаг гадарга дээр гарсан зурвастай холбоотой байна. Голуудын шүлжээ сайн хөгжсөн, зарим нь гол нурууныхаа ноён оргилуудаас эх авдаг бол зарим нь гол нурууг нэвт зүссэн голын хөндийтэй байна. Хажуу эрс, хадархаг 25 градусаас их хэвгийтэй байна. Харин усны эдэгдэл, физик өгөршил нэн эрчимтэй явагдсан. Түр зуурын усны урсгал усны үйлчлэлээр сайр олноор үүсч зарим газар шигүҮ оршдогийн улмаас уулын хажуу бэлийг сархиаг болгожээ. Бурхан Буудайн нурууны ар болон бруун талд өргөн урт бэл үүссэн бий. Баян сайр, Цагаан бургасны гол, Үертийн амны сайр дунджаар 15 км үргэлжилж Бигэрийн хонхортой залгана.

Бурхан буудайн нуруу говь цөлийн нөлөөлөд нилээд орсон учир ихээхэн элэгдэж эвдэрсэн тул уулсын орой шовх хад чулуу, хажуунууд нь ихэвчлэн эгц, хад асга ихтэй болж хувирсны цэрэгцээ урсгал ус ховор учраас тэрхүү элэгдэл эвдрэлийн материал хол зөөвөрлөгдөх боломжгүй тул уулсын хажууд хуримтлагдсаар асар урт бэлийг бий болгожээ.

Монголын бэлийн тухай бэлийн геологи, морфологи, түүний гарал үүсэл, морфоструктурын шинж чанарыг Монгол Алтайн уул үүсэх хөдөлгөөнтэй холбон бичсэн байна [6].

Бэлийн хэвгий талын гадарга уулнаас yрсах маш олон тооны гол горхи ганга жалгаар хэрчигдсэн байна. Бэлүүдийн налуу уулнаас холдох тусам багасдаг. Бэл бол элэгдлийн тэгшрэл идэвхтэй явагдаж байгаа орчин үеийн рельефийн хэлбэр юм. Түр зуурын урсгалтай хуурай сайр хөндийгөөр хэрчигдсэн бүс юм. Дээд хэсэгтээ элэгдлийн хэсэгчлэлийн шигүҮ маш их байхад доод хэсэгтээ шигүү гүн багасч ухрах элэгдэл их байна. Бэлийн дээд хэсгийг хайрган, доод хэсгийг шаварлаг давхрагатай гэж ялган болох юм. Түр зуурын урсгалтай сайр дээд бүсд шигүY юм. Бэлийн дээд бүс нь нилээд налуу 6-10 $12-13^{0}$ градус налуутай байна. Томоохон хуурай сайрын өргөн 100-300 м гүн нь 2-4 м байна. Ёроол нь тэгш, бул чулуу дэвсэгдсэн, муу ангилагдсан хайрга бүхий ихэнхдээ овон товонтой. Сайрын эрэг нь эгц байна. Эрэг нь пролювийн томоохон ширхэгтэй хэвтээ үелсэн зузаан үе давхаргаас бүрдсэн байна. Бурхан буудайн нурууны хойд болон зүүн бэлийн хэвгий талаар элс нилээд талбайд тархаж харьцангуй тэгш нимгэн үеэр хучиж тогтсон байдаг.

Бурхан буудайн нурууны хойд, зүүн өвөр бэлд үлдэгдэл уулс байхгүй бэлийн зарим хэсэгт аараг толгод бий.

Геоморфологийн товч. Геоморфологийн мужлалтын хувьд Монгол ба Говийн Алтайн уулт их мужийн Монгол Алтайн мужийн Монгол-Алтайн гол нуруунд багтана. [3].

Уулсын тогтолцооны ерөнхий дүр төрх нь баруун хойноосоо зүүн урагш сунаж тогтсон хэлбэртэй нэг цулдам уулс, голын хөндийнүүдээр хэрчигдсэн байдалтай юм. Бурхан Буудайн нуруу нь өргөгдөл, элэгдэл эвдрэлтэй холбоотой уулын хяр нь бөмбөгөр, хажуу нь налуу ихтэй, олон нарийн жалгаар огтлогдсон байдаг. Бурхан Буудайн нуруу хотгор гүдгэрийн гадаад төрх байдал нь геологийн урт удаан хугацааны туршид элэгдэл, усны идэгдлийн үйл явцад автсаны улмаас уулсын орой ихэвчлэн шовх хадан хана, асга нургаас тогтсон байна.

Энэ нуруу нь каледоны атриат бүсэд хамрах бөгөөд дунд болоод шинэ төрмөлийн эриний сүүл үеийн шинэхэн тектоник хөдөлгөөнд хүчтэй автагдан, гадаргын байдал нь альпийн хэв шинжит уулсын төрхийг олжээ.

Хотгор гүдгэрийн морфогенетик хэв шинж: Бурхан буудай уул нь тектоник хөдөлгөөнөөр үүсч өндөрт өргөгдсөн болон царцдасын гадаад хүчний элэгдлээр засварлагдан өөрчлөгдөж байгаа тектоникэлэгдлийн хэв шинжит хотгор гүдгэр бүхий уулт тогтолцоонд орно. Энэ нурууны гадаргад тектоник-элэгдлийн хэв шинжит хотгор гүдгэр зонхилох байрыг эзэлнэ. 
Шинэхэн тектоник хөдөлгөөнд хүчтэй автаж өндөр болсон эртний мөсдөлийн ул мөр бүхий өндөр уул юм.

Эдгээр уулс каледонитийн хожуу үеийн атриат тогтолцоо бүхий суурь дээр шинэхэн тектоник хөдөлгөөн, тус орны бусад нутгаас илүҮ эрчимтэй болсны нөлөөгөөр буюу царцдасын дотоод хүчний үйл ажиллагаа, гадаад хүчний үйл ажиллагаагаас хавьгүй хүчтэй байсны улмаас өндөрт өргөгдсөний зэрэгцээ дөрөвдөгч галвын туршид 1-3 удаа мөсдөж, ерөнхийдээ эгц хажуутай, шовх оройтой ян сарьдаг голлосон өндөр уулс юм [3].

Бурхан буудайн нурууг 1969 онд боловсруулсан Монгол орны физик газарзүйн мужлалтаар [2] Алтайн уулархаг их мужийн Монгол Алтайн мужийн Алтайн зүүн хэсэг Б тойрогт багтаасан бол Монгол оны физик газарзүйн шинэчилсэн мужлалаар /1999/ төв Азийн заримдаг цөл, цөлийн их мужийн Говь-Алтайн бэлэрхэг уулын мужийн Хар азарга-Гичгэний нурууны дэд мужид [4] хамааруулсан байна.

Бурхан буудайн нурууны Баян сайрын гол, Үертийн голууд эх авдаг нуруунд 3448м өндөрт томоохон талбайтай эртний тэгширлийн гадарга бий. Энэ тэгш хавгайн хонхор хотост хярын нуурууд үүссэн нь бий. Мөн Дэвсэгийн нуруунд 2700 м өндөрт эртний тэгширлийн гадарга хадгалагдан үлджээ.

Бурхан буудайн нуруу нэгэн хэвийн тавцан хэлбэрийн хяртай, нуруудын дээд хэсэг нь ихээхэн тэгширсэн, эгц налуу хажуу бүхий гадаргын хэлбэртэй. Уулсын оройгоор сэрвэн хад цохио мэр сэр тохиолдоно. Уулсын хажуу эгц цавчим, элэгдэл эвдрэлээр үүссэн асга нураг ихтэй. Уулын хажууд үүссэн ийм хурдас нь байнга нэмэгдэж шилжиж байх ба уулын дээд хэсгээр асганы ширхэг бага байхад уулын хормой орчимдоо нургийн хурдасны хэмжээ томорч налуу багассантай холбоотой хөдөлгөөн нь багасна. Уулын оройн хад чулуу халуун хүйтний элэгдэл эвдрэлээс болж хагарч бутран доош бууж голын хөндийд том том бул чулуу овоорсон нь бий. Дулааны улиралд цас борооны үед хад нурж асга нураг ихээр үүснэ. Асга нураг үүсээгүй уулын ар, энгэр бараг байхгүй. Дан ганц асга чулуунаас тогтдог, хамт Үүссэн хөрс шороо нь усаар угуугдан зөөгдөж, үргэлж шилжиж байдаг болохоор хөрс үүсч ургамал ургах нөхцөл байхгүй юм.

Энэ нуруунд шохойн чулуу ихээр тархсан төдийгүй гадаргад ихээр гарч Цахир боом (3082.0м), Цахир уул (2906.0м) зэрэг шохойн чулуунаас тогтсон уул нурууг Үүсгэжээ.

Орчин үеийн нэг чухал хүчин зүйл бол хүйтний өгөршил уулын чулуулгийн хуримтлал, асгарга үүссэн байхад урсгал усны үйл ажиллагаагаар өргөн бэлүүд хушуу туудас үүсгэн ихээхэн бартаажсан байна.

\section{Гадаргын хэвгий}

Бурхан Буудайн нуруу далайн түвшнээс дээш 2000-3765м хүртэл өндөр өргөгдсөн, уул нурууд нь тэгшивтэр, бөмбөгөр оройтой орой хяртай, хажуунууд нь нилээд гүн хэрчигдсэн, үлдэгдэл хад цохио элбэгтэй, техтоник гаралтай ан цавыг дагаж тогтсон гүн нарийн хавцал, хөндийгөөр ихээхэн хэрчигдсэн байна. Энэ нурууны оргилууд нь 3000 метрээс дээш сүндэрлэх ба эгц хажуу нь гол төлөв хад асга, нураг чулуунаас тогтоно. Тус нурууны гадаргын $13.06 \%$ нь $25^{\circ}$-аaс дээш налуутай юм. Нийт талбайн $34.02 \%$ буюу $43,160.85$ га талбайг $3^{\circ}$ - $9^{\circ}$-ийн налуу гадарга эзэлнэ.

Ийм налуутай гадаргад 1900 м-ээс доош өндөртэй Бурхан буудайн нурууны түр зуурын урсгалтай голууд болон хуурай сайруудаар хэрчигдсэн уулын хормой бэлүүд орно.

$9^{\circ}$ - $15^{\circ}$-ийн налуу гадарга нь Бурхан буудайн уулт тогтолцооны захын хэсэг, тус нурууны 2500 м-ээс доош өндөрт тархана. Ийм налуу гадарга нийт талбайн 19.2 \% буюу 24,441.9 га талбай эзэлнэ. 


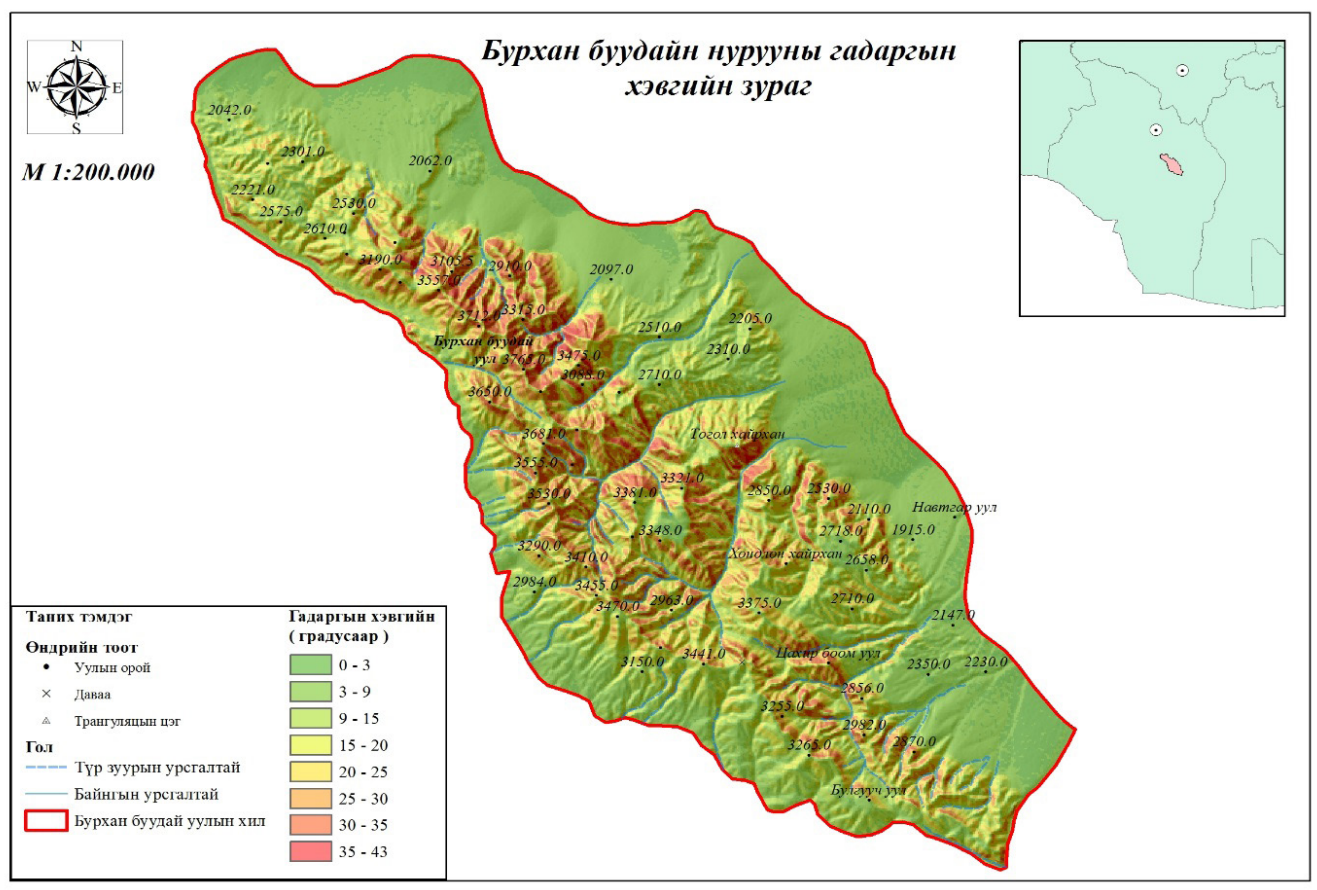

$15^{\circ}$ - 20-ийн налуу гадарга нь Бурхан буудайн нурууны 2500-2600 м өндөртэй уулсын хажууг хамарна. Ийм гадарга нийт талбайн 13.0 \% буюу 16,523.1 га талбайг эзэлнэ.

$20^{\circ}$ - 25-ийн налуу гадарга 2600-3200 м-ийн өндөртэй нутгийг хамарна. Нийт талбайн 11.4 \% буюу $14,480.02$ га талбайг эзэлнэ.

$25^{\circ}-30^{\circ}$-ийн налуутай гадарга Бурхан буудайн нурууны 3200-3400 м-ийн өндөрт ихэвчлэн тархах ба нийт талбайн 8.7\%-ийг буюу 11,143.6 га талбайг эзэлнэ.

$30^{\circ}$ - $35^{\circ}$-ийн налуу гадарга 5691.6 га талбайтай бөгөөд нийт талбайн 4.4 \%-ийг эзэлж оршино. Хажуугийн үйл явц эрчимтэй явагддаг бартаажсан эгц хажуу бүхий 3400-3600 м-ийн өндөртэй гадарга хамарна.

$35^{\circ}$ - с дээш налуу гадарга Бурхан буудайн нурууны өндөр уулсын оройн хэсэг, ян сарьдаг бүхий нутаг орно. Нийт гадаргын 0.06 \% буюу 726.6 га талбайг эзэлнэ.
Хэрчигдлийн шигүҮ: Бурхан Буудайн нуруу нь эртний мөсдлийн ул мөр бүхий өндөр уулсын район тул гадарга, геологийн тогтоцын онцлогоос болоод хамгийн их хэрчигдсэн нутгийн нэгэнд орно.

0.5 км/км² хүртэл шигүү хэрчигдэлтэй гадарга $10,747.5$ га талбайтай бөгөөд нийт талбайн 8.4 \%-ийг эзэлж оршино.

0.5-1 км/км ${ }^{2}$ шигүY хэрчигдэлтэй гадарга 70,678.1 га талбайтай бөгөөд нийт талбайн 55.7 \%-ийг эзэлж оршино. 1-1.5 км/ км² шигүҮ хэрчигдэлтэй гадарга 31,649.3 га талбайтай бөгөөд нийт талбайн 24.9 \%-ийг эзэлж оршино.

1.5-2 км/км² шигүү хэрчигдэлтэй гадарга 7,843.2 га талбайтай бөгөөд нийт талбайн $6.1 \%$-ийг эзэлж оршино.

2-2.5 км/км² шигүү хэрчигдэлтэй гадарга $3,812.9$ га талбайтай бөгөөд нийт талбайн $3.0 \%$-ийг эзэлж оршино.

2.5-3.0 км/км²-aас дээш шигүу хэрчигдэлтэй гадарга 1,560.6 га талбайтай бөгөөд нийт талбайн $1.2 \%$-ийг эзэлж оршино. 


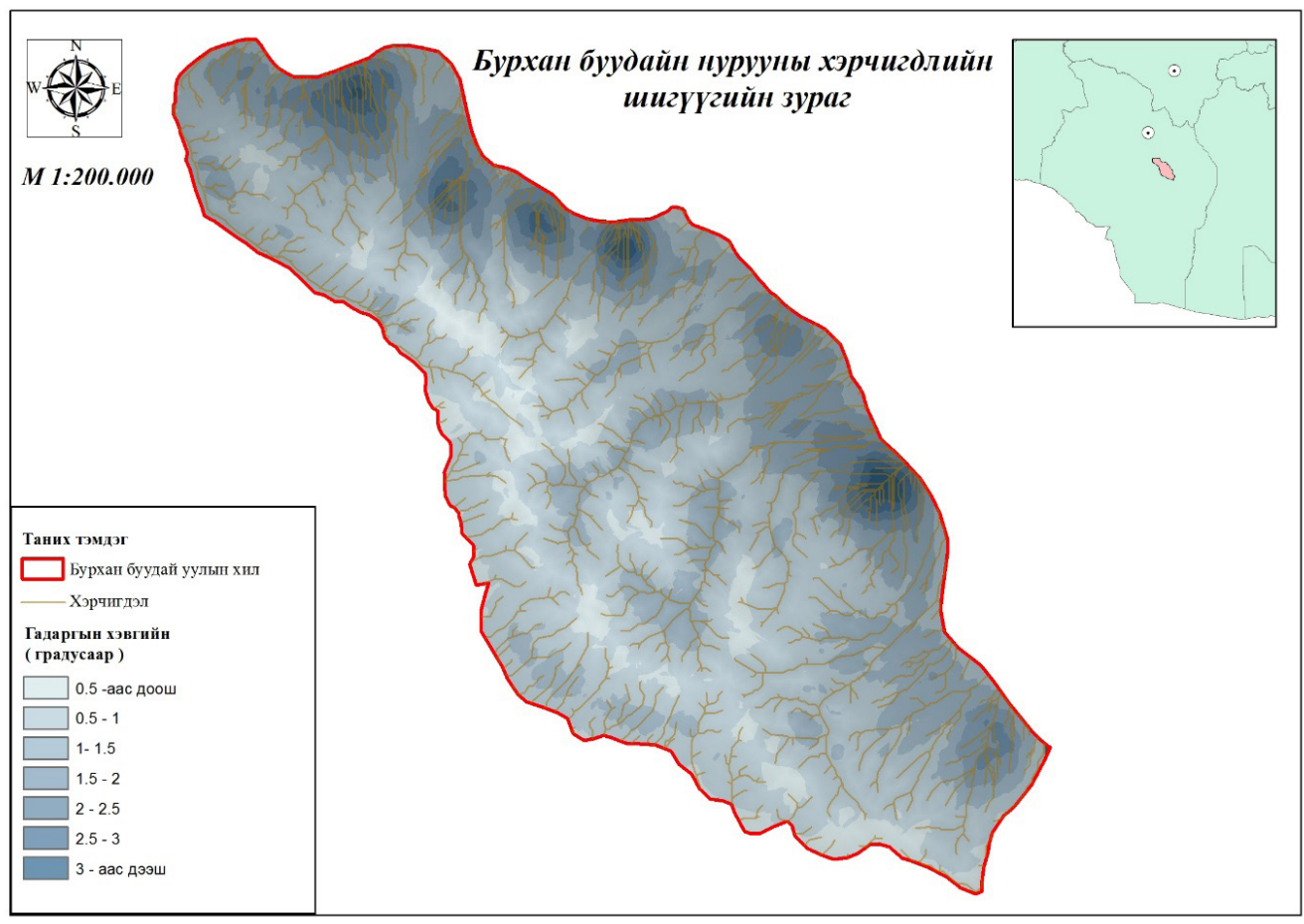

3.0 км/км²-аaс дээш шигүү хэрчигдэлтэй гадарга 546.7 га талбайтай бөгөөд нийт талбайн 0.4 \%-ийг эзэлж оршино.

\section{Эртний мөсдөл}

Бурхан Буудайн нурууны нэг онцлог бол хотгор гүдгэрийг үүсгэгч орчин үеийн үйл явцад дөрөвдөгч галвын турш үргэлжилсэн эртний мөсдлийн уул мөр хадгалагдан үлдсэн явдал юм. Бурхан буудайн нуруу харьцангуй өндөр бөгөөдорчин тойрны говь цөлийн ландшафтын хуурай уур амьсгалд геологийн урт удаан хугацаанд автагдаж байсан болохоор оргилууд нь орчин үеийн мөсдөл байхгүй, эртний мөсдөлийн ул мөр хунх тус нуруунд хааяа нэг тохиолдох ажээ. Энэ нуруунд Монгол Алтайн бусад уулсад түгээмэл ажиглагддаг эртний мөстлийн ул мөр ховор юм. Мөстлийн улмаас уулын дээд хэсэгт үүссэн хунх, хааяа нэг задгай хунхын хэлбэр ажиглагдах ба мөсөн голын үйл ажиллагаагаар үүссэн тэвшин хөндий, морены хурдас байхгүй байна.
Ус зүй

Бурхан буудайн нуруунаас Чацрангийн гол (40.4км), Үертийн гол (21.1км), Зуслангийн гол (15.3 км), Баян сайр (19.7 км), Цагаан бургасны гол (187.7км), Дунд гол (7.0 км), Урд гол (8.2 км), Хойд гол (3.9 км), Уртын гол (8.0 км), зэрэг голууд эх авч урсана. Эдгээр цэнгэг устай голуудын олонх нь гол нуруунаасаа эх авч эгц цавчим хавцлуудын дундуур урсана. Байнгын урсгалтай эдгээр голууд хур бороо цасны усаар тэжээгдэх бөгөөд зуны бороо хаврын шар усны үед үерлэж Халиун, Бигэрийн нуурын хотгорт усаа юүлнэ. Өвлийн улиралд мөс тошин үүсгэж голын хөндий хавцлыг дүүргэн мөсөөр хаана. Намар зундаа тогтмол урсан уулынхаа амнуудаас бараг хэтэрч чадахгүй ууршиж голын сайрандаа шингэнэ.

Бурхан буудайн гол нурууг гүнзгий хавцлуудаар зүсэн гарсан нэвт хөндийтэй гол байхгүй юм. Тус нуруу нь маш гүн хэрчигдсэн, уулсын хажуу маш их налуу, заримдаa бараг эгц хажууг үүсгэсэн 
байна. Ихэнх төлөв хавцал үүсгэсэн бий. Ерөнхийдөөнарийн хавцлын хэсэг нь үндсэн чулуулаг гадарга дээр гарсан зурвастай холбоотой байна. Голуудын сүлжээ сайн хөгжсөн зарим гол нь гол нурууныхаа ноён оргилуудаас эх авна. Хажуу эрс, хадархаг 25 градусаас их хэвгийтэй байна. Харин усны элэгдэл физик өгөршил нэн эрчимтэй явагдсан. Түр зуурын усны урсгал усны үйлчлэлээр сайр олноор үүсч зарим газар шигүҮ оршдогийн улмаас уулын хажуу бэлийг сархиаг болгожээ.

Голууд нь цас борооны усаар тэжээгдэх ба тэжээлийн 60-70 \% цас, борооны ус байна. Гадаргын усны зэрэгцээ газар доорх ус элбэг учир гуу, жалга, уулын ам хөндий, хормойгоор булаг шанд болж ундарна. Уулын хормой хаялага гол мөрний хөндий дагуу ихээхэн намагжсан байна. Голуудын хөндий эхэн хэсэгтээ давчуу нарийн, түүний морфологи бүтэц нь $\mathrm{V}$ хэлбэрийн зүсэлт үүсгэдэг зүй тогтол энд тодорхой ажиглагдана.

\section{Ландшафт}

Бурхан буудайн нуруунд уулын хээрийн ландшафт хамгийн өргөн дэлгэр хөгжсөн байдаг юм. Уулын хээрийн ландшафтад өндөр уулын хээрийн бүдүүн ялзмагт хөрс голлоно. ...УГ хөрсний Алтайн уулын системд онцгой ялгаран харагддаг онцлог байдлыг харгалзан бид энэ нутгийг ландшафтын бие даасан дэд хэв шинж болгож уулын хээрийн ландшафтын Алтайн дэд хэв шинж гэж ялган үзлээ... [7] Бурхан буудайн нуруугаар алаг өвстботуульт, алаг өвс- жижиг дэгнүүлт, үетэн ботуульт уулын хээрийн ургамалшил зонхилно. Бурхан буудайн нуруунд жимс, жимсгэнээс тошлой, өндөр улаагана (улаалзгана), өргөст нохойн хошуу, үхрийн нүд говьдоо хармаг ургана. Эмийн ургамлаас таван салаа, ягаан мүгэз (алтан гагнуур), вансэмбэрүү (нөмрөгт банздоо), согоо суман, эмийн банбай, хошоонгор, цагаан шарилж, морин зээргэнэ, хонин зээргэнэ, алаг цэцэгт башир, үст хөөнгө ортууз, боргоцойрхуу ортууз, эгэл марал цэцэг, говийн ганга, дэгд, үсхий ангалзуур, эгэл өмхий өвс, орогдуу нохойн хэл, марцны хоржигнуур, исэглэн хурган чих ургана. Мөн ашигт ургамлаас хонин арц, гишүүнэ, хурган мэхээр, цагаан мөөг, Алтайн сонгино, ихээхэн тархсан байдаг.

Бурхан буудайн нуруу Монгол орны амьтны газарзүйн мужлалаар Уулархаг Азийн дэд их мужийн Монгол Түвдийн мужийн Баруун хойд Монголын тойрогт хамаарагдана. (А.Г.Банников, 1954) Туурайтан аймгийн дотроос аргал, янгир, махчин амьтдаас ирвэс, хадны суусар, чоно, үнэг, хярс, мануул, шилүүс, өмхий хүрэн, үен түгээмэл тархсан байдаг. Мэрэгч амьтдаас тарвага, зурам, оготно, үхэр огдой, туулай, бор хулгана, шар сүүлт, чичүүл, алаг даахай, жигүүртнээс ятуу, хахилаг, хойлог, ногтруу, тас, бүргэд, ууль, тагтаа, улаан хошуут, ээрүүл шувуу, элээ, бэгбаатар, шаазгай элбэг тохиолдоно.

\section{Xөpc}

Бурхан буудайн нуруу хөрс газарзүйн мужлалтаар говийн их мужийн Говь Алтайн болон Алтайн өвөр говийн дэд мужид өндрийн бүсжлийн Алтайн хэвшинжид хамаарна [8]. Энэ нуруунд өндөр уулын хээрийн хар хүрэн хөрс голлон тархана. Энд хөрс харьцангуй хүйтэн хуурай нөхцөлд тогтворжих ба нэг талаас чийг нилээд дутагдалтай, нөгөө талаас сүрхий хүйтэн байдаг болохоор хөрс үүсвэрийн үйл явц өвөрмөц шинжтэй. Бурхан буудай нурууны ap хажуу шинэсэн ойтой. Уулын ойн хар хүрэн хөрс тус нурууны 2900-3000м хүртэл үнэмлэхүй өндөрт тархсан байна.

\section{Уур амьсгал.}

Бурхан буудайн нуруу нь хуурай сэрүүн зунтай, хахир өвөлтэй уур амьсгалын мужид ордог. Алтайн цаг уурын станцын мэдээгээр агаарын температурын хэлбэлзэл $60-70^{\circ} \mathrm{C}$, хоногийн хэлбэлзэл $20-25^{\circ} \mathrm{C}$-д хүрч жилийн дундаж температур $-2^{\circ} \mathrm{C}$ байна. Зуны урирал их халуун биш 7-р сарын 
дундаж температур $16^{\circ} \mathrm{C}$ үнэмлэхүй их температур $+29,7^{\circ} \mathrm{C}$ хүрнэ. 1 -р сарын дундаж температур $-20^{\circ} \mathrm{C}$ үнэмлэхүй хүйтэн $-42^{\circ} \mathrm{C}$ хүрдэг байна. Нарны гийгүүлэх хугацаа 2800 цаг, нарны нийлбэр цацраг 1300 $\kappa В \mathrm{~T} / \mathrm{M}^{2}$, агаарын температурын хоногийн дундаж $+10^{\circ} \mathrm{C}$-аaс дээш байх өдрийн тоо 90-аас бага байна. Энд жилд дунджаар 200250 орчим мм тунадас унадаг. Тунадасны ихэнх нь зуны улирал буюу ид борооны үе 7-р сард унана. Харин өвлийн улиралд цас нилээн их унана. Цасан бүрхүүл бүхий үе 11-p сарын 20-ноос 4-p сарын 10 хүртэл үргэлжилж тогтвортой цасан бүрхүүл 100 хоног байна. Жилийн ерөнхий үүлшилт 5 баллаас хэтрэхгүй. Салхины хүч их, жилийн дундаж хурд 3.2 м/сек бол хамгийн их нь 34 м/сек-ээс хэтрэхгүй [9].

\section{ДҮГНЭЛТ}

Бурхан буудайн нуруу нь гадаргын харьцах өндрийн байдал, уул зүйн байрлал, тогтоцын хувьд Монгол Алтайн уулт тогтолцоог бүрэлдүүлж байгаа гол нуруудын нэг юм.

Энэ нуруу нь Монгол Алтайн гол нурууны ландшафт, гадаргын хэв шинж, хэлбэр, хурдас чулуулгийн элэгдэл, хуримтлал, гадаргын үүсэл хөгжлийн төлөөлөл болох бөгөөд Хар азаргын нуруу, Гичгэний нурууны хооронд оршиж Монгол Алтайн уул тогтолцооны нэгэн хэсэг болж байдаг юм.

\section{Аиигласан бүтээлийн жсагсаалт}

1 Мурзаев.Э.М. Монгольская Народная Республика /Физико-географические описание/. Москва.1952. стр 297/ .

2. Цэгмид Ш. Монгол орны физик газарзүй. УБ., 1969. /336,364-р хуудас/

3. С.Жигж Монгол орны хотгор гүдгэрийн үндсэн хэв шинж, УБ., 1975. / 50,88-р хуудас/

4. Geological map of Mongolia. Scale 1:1.000.000 Ulaanbaatar 1998.

5. Даш Д .Монгол орны ландшафт экологийн зарим асуудлууд, УБ., 2000, 93,95-р хуудас/

6. Тимофеев Д.А, Чичагов В.П. Бэли Монголии. Очерки физической географии Монголии. УБ., 2006

7. Монгол орны ландшафт-экологийн асуудал, УБ., 2010, 115,127-р хуудас

8. Монгол улсын өрнөд бүс, УБ., /1999.143-р хуудас/

9. Национальный атлас МНР, 1990.,/ стр 54-58/ 